\title{
Macrophage Inflammatory Protein-1 $\alpha$ Relates to the Recruitment of Inflammatory Cells in Myosin-Induced Autoimmune Myocarditis in Rats
}

\author{
Tetsuya Toyozaki, Toshihiro Saito, Hirokazu Shiraishi, Yoshiaki Tsukamoto, \\ Hiroyuki Takano, Toshio Nagai, Kenzo Hiroshima, Hidemi Ohwada, \\ Shigeru Ishiyama, and Michiaki Hiroe
}

Division of Pathology (TT, KH, HO), Institute of Pulmonary Cancer Research, and Third Department of Internal Medicine (TS, HS, YT, HT, TN), Chiba University School of Medicine, Chiba; and Division of Cardiology (SI, MH), Second Department of Medicine, Tokyo Medical and Dental University, Tokyo, Japan

\begin{abstract}
SUMMARY: In experimental autoimmune myocarditis (EAM) there is a characteristic initial focal inflammatory response in the myocardium, induced mainly by $\mathrm{CD}^{+} \mathrm{T}$ cells and macrophages, which leads to massive myocardial damage. Macrophage inflammatory protein-1 $\alpha$ (MIP-1 $\alpha$ ) induces chemotaxis in lymphocytes, eosinophils, basophils, and macrophages. We assessed the potential role of MIP- $1 \alpha$ in the pathogenesis of EAM in rats immunized with porcine myosin. Following immunization, the levels of MIP- $1 \alpha$ mRNA in EAM showed an increase on Day 11 and peaked on Day 17. MIP-1 $\alpha$-positive cells were predominantly immunoreactive to OX6 antibody (dendritic cells) and ED2 antibody (resident macrophages) by Day 14. Marked cellular infiltration was seen on Day 17 with the major population of MIP-1 $\alpha$-positive cells also positive for ED1 (inflammatory macrophages). We then examined the association of MIP-1 $\alpha$ with the development of myocardial inflammation. Rats were divided into three groups: Group A consisted of EAM rats $(n=10)$; Group B consisted of EAM rats treated with anti-MIP- $1 \alpha(1 \mathrm{mg} / \mathrm{kg})$ on Days 11,13 , and 15 , before the onset of initial inflammation $(n=5)$; and Group C consisted of EAM rats treated with anti-MIP-1 $\alpha$ from the start of the initial inflammation on Days 14, 16, and $18(n=5)$. Rats were euthanized on Day 21 and three transverse sections of the heart were prepared to determine the percentage of the area affected by inflammatory lesions. This area of inflammation was significantly smaller in Group B $(27 \pm 4 \%)$ than in Groups A $(51 \pm 6 \%)$ or C $(50 \pm 6 \%)(p<0.01)$, indicating that the administration of antibody before the initiation of inflammation, in part, will inhibit myocardial inflammation. These data suggest that MIP-1 $\alpha$ may play an important role in the recruitment of inflammatory cells in the early stages of EAM. (Lab Invest 2001, 81:929-936).
\end{abstract}

$A$ key feature of myocarditis is the infiltration of inflammatory cells into the myocardium with necrosis of adjacent myocytes (Woodruff, 1980). Although the mechanism by which these cells traffic into the myocardium and accumulate there is not well understood, the phenomenon is generally considered to be induced by the local production and secretion of chemotactic cytokines (chemokines) by a wide variety of stimulated cell types. Chemokines are subdivided into two major classes depending on the position of the two cysteines, C-X-C and C-C, (Oppenheim et al, 1991). The C-C family is primarily chemotactic for monocytes/macrophages, T lymphocytes, basophils, and eosinophils (Davatelis et al, 1988; Schall, 1991; Taub et al, 1993). Macrophage inflammatory protein- $1 \alpha(\mathrm{MIP}-1 \alpha)$ is a $\mathrm{C}-\mathrm{C}$ chemokine produced by macrophages (Wolpe et al, 1988), neutrophils (Kasama et al, 1993), eosinophils

Received December 21, 2000.

This work was supported by The Inohana Foundation (Chiba University), Chiba, Japan.

Address reprint requests to: Dr. Tetsuya Toyozaki, Division of Pathology, Institute of Pulmonary Cancer Research, Chiba University School of Medicine, 1-8-1 Inohana, Chuo-ku, Chiba, 260-8670 Japan. E-mail: toyozaki@za2.so-net.ne.jp
(Costa et al, 1993), and inflammatory fibroblasts (Lukacs et al, 1994). It is expressed as one of the first C-C chemokines to appear at sites of inflammation (Natori et al, 1997). The release of chemokines such as MIP-1 $\alpha$, therefore, is regarded as a crucial step in cell recruitment, necessary for the initiation and maintenance of inflammatory responses (Cook, 1996; Strieter et al, 1996).

In Coxsackievirus B (CVB) myocarditis, many of the pro-inflammatory chemokines, ie, MIP-1 $\alpha$, MIP-2, monocyte chemoattractant protein-1 (MCP-1), MCP-3, cytokine-regulated gene-2, and RANTES, are up-regulated during the course of infection (Gebhard et al, 1998; Kishimoto et al, 2000). MIP-1 $\alpha$ transgenic knockout mice are resistant to Coxsackievirus B3 (CVB3)-induced myocarditis seen in infected wild-type mice (Cook et al, 1995). CVB3-induced myocarditis was also reduced in perforin knockout mice. MIP-1 $\alpha$ mRNA was barely detectable in CVB-infected perforin knockout mice, whereas MCP-1, MCP-3, cytokineregulated gene-2, and RANTES mRNA expression increased in response to CVB infection in both perforin knockout and wild-type mice. These data suggested that perforin-mediated lysis of infected myocytes triggered phagocytic infiltration and the consequent ex- 
pression of MIP-1 $\alpha$, inducing further lymphocytic infiltration, which in turn caused further tissue damage (Gebhard et al, 1998). Many experiments suggest that a virus-induced autoimmune response is caused by damaged myocytes exposing heart antigens (Horwitz et al, 2000; Rose, 2000) or molecular mimicry between epitopes shared by the virus and antigens of the heart (Badorff et al, 1999; Gauntt et al, 1991, 1993). It therefore seems likely that MIP- $1 \alpha$ plays a crucial role in an autoimmune mechanism mediated by $\mathrm{T}$ cells during myocarditis.

Experimental autoimmune myocarditis (EAM) is a $T$ cell-mediated disease (Hanawa et al, 1993; Kodama et al, 1992; Smith and Allen, 1991) characterized by the infiltration of $\mathrm{T}$ cells and macrophages, leading to massive myocardial necrosis, which later develops into dilated cardiomyopathy in the chronic phase (Kodama et al, 1994). EAM is similar to the pathogenesis of some forms of human myocarditis, such as giant cell myocarditis, hypersensitivity myocarditis, and idiopathic myocarditis with a chronic or recurrent course (Kodama et al, 1991, 1994). EAM is an ideal model for exploring the specific immune effector mechanisms that cause ongoing myocardial damage in the absence of the complexities induced by prior viral infection (Smith and Allen, 1991). In this study we assessed the potential role of MIP- $1 \alpha$ in the pathogenesis of EAM in rats immunized with porcine myosin.

\section{Results}

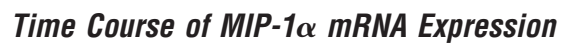

Figure 1 shows representative results of reversetranscription polymerase chain reaction (RT-PCR) of MIP $-1 \alpha$ mRNA. The expression of MIP $-1 \alpha$ mRNA was enhanced in the myosin-immunized rats compared with the control rats. Figure 2 is a graphic representation of the time course of MIP- $1 \alpha$ mRNA expression normalized to the level of glyceraldehyde-3-

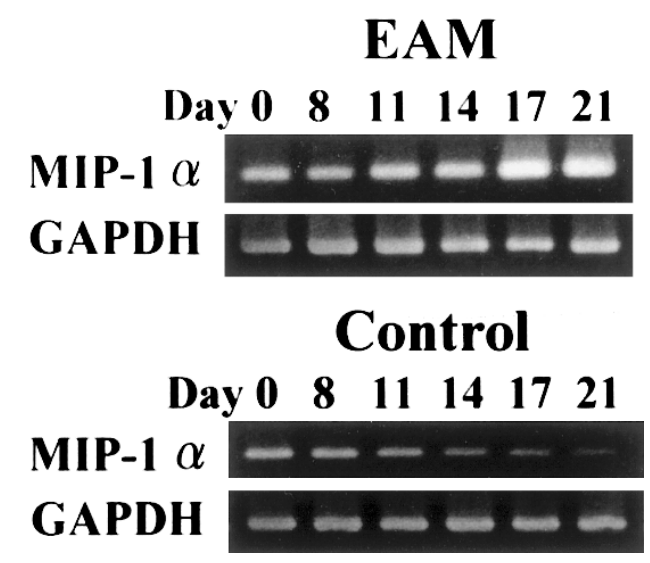

Figure 1.

Macrophage inflammatory protein-1 $\alpha$ (MIP-1 $\alpha$ ) mRNA-expression in experimental autoimmune myocarditis (EAM). RNA was isolated from five normal rats (Day 0), five myosin-immunized rats (EAM), and three control rats (Control). mRNA was reverse transcribed and gene-specific primers were used for polymerase chain reaction analysis.

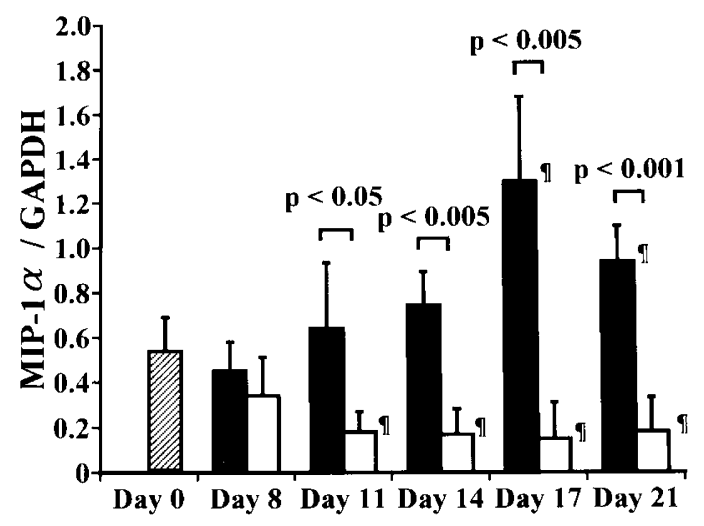

Figure 2.

Time course of MIP- $1 \alpha$ mRNA expression in EAM. The amounts of MIP- $1 \alpha$ mRNA were normalized to the level of glyceraldehyde-3-phosphate dehydrogenase (GAPDH) at each time point. The ratio of MIP- $1 \alpha /$ GAPDH in EAM rats (solid bars) was higher than in control rats (open bars) on Days 11, 14, 17, and 21. ๆ, $p<0.05$ compared with normal rats (hatched bar).

phosphate dehydrogenase (GAPDH) mRNA. The ratio of the intensity of the MIP- $1 \alpha$-specific signal to the intensity of the GAPDH-specific signal was $0.54 \pm$ 0.15 in normal rats (Day 0 ) and slightly subsided by Day 8 in myosin-immunized rats $(0.46 \pm 0.13)$ and control rats $(0.34 \pm 0.17)$. In the myosin-immunized rats, expression of MIP-1 $\alpha$ mRNA tended to increase, starting from Day 11 (0.64 \pm 0.29$)$, and peaked on Day 17 (1.29 \pm 0.38$)$. Figures 1 and 2 show a trend of decreasing MIP- $1 \alpha$ control values compared with the normal values from Day 8 to Day 21 .

\section{Characteristics of MIP-1 $\alpha$-Positive Cells}

The onset of EAM after immunization with cardiac myosin on Day 14 showed infiltrating mononuclear cells, including OX6-, ED2-, W3/25-, or ED1-positive cells, although necrosis of myocytes was rare (initial inflammation). Double staining using anti-MIP-1 $\alpha$ and ED1, ED2, OX6, OX19, or OX33 antibody revealed MIP-1 $\alpha$ immunoreactivity in ED2-positive cells and OX6-positive cells that were scattered throughout the interstitium of normal rat hearts (Fig. 3). By Day 14, MIP- $1 \alpha$-positive cells were predominantly immunoreactive for OX6 and ED2. Mononuclear cells were scattered throughout the myocardium, but by Day 11 had gathered together gradually, frequently forming clusters in the myocardium by Day 14. Most of these clustering cells were composed of OX6-positive cells immunostained with the MIP-1 $\alpha$ antibody (Fig. 3). Analysis of in situ RT-PCR revealed that MIP- $1 \alpha$ transcripts were amplified and detected in mononuclear cells. This positive signal was more clearly present in clustering cells on Day 14. However, MIP- $1 \alpha$ transcripts were not detectable in cardiac myocytes. Signal was also absent when RT enzyme was omitted (Fig. 3). Day 17 showed marked cellular infiltration with the major population of MIP- $1 \alpha$-positive cells also ED1-positive. 

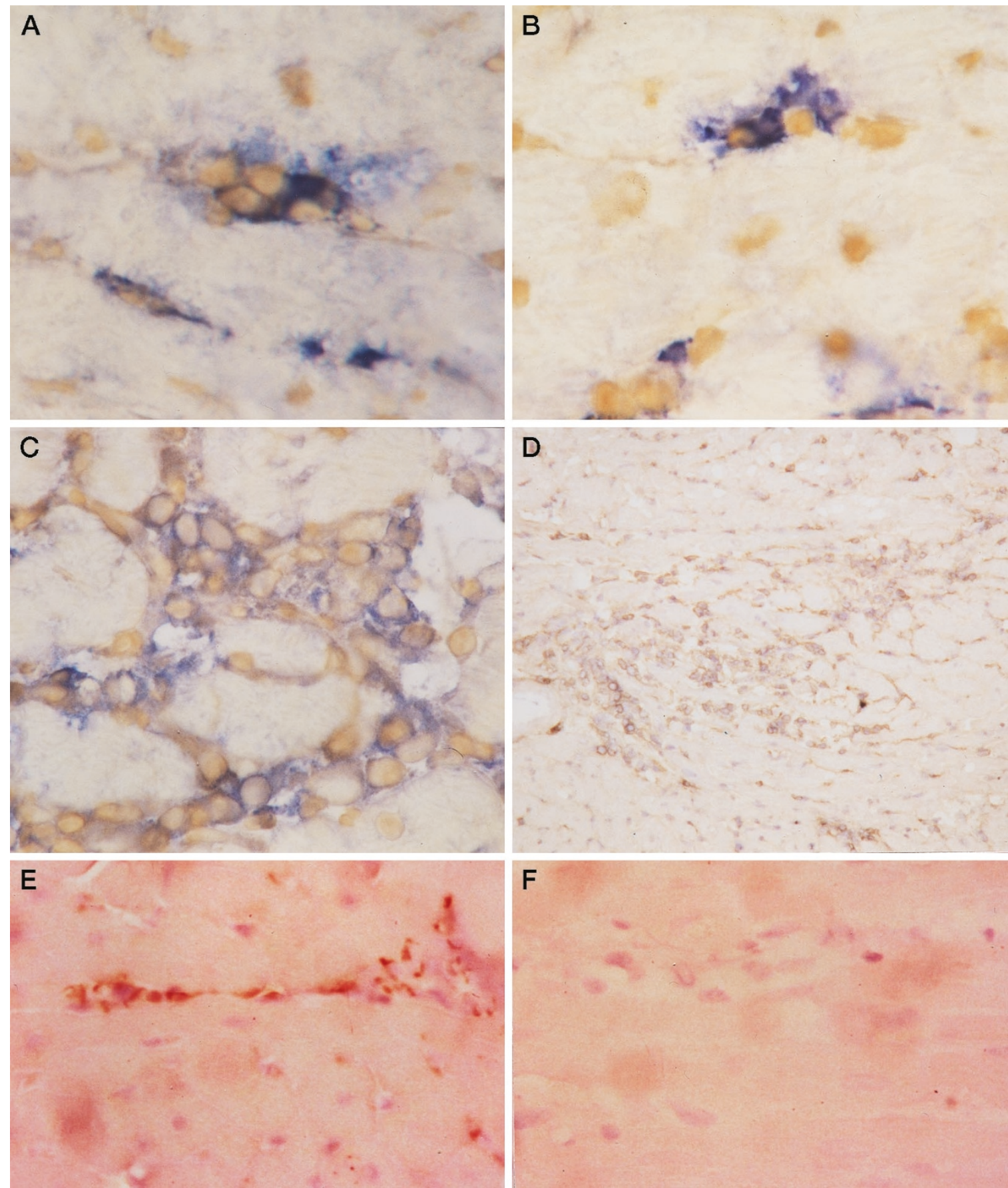

\section{Figure 3.}

Immunohistochemical staining (A to D) and in situ RT-PCR (E and F) in normal rats and myosin-immunized rats. A to C, MIP-1 $\alpha$ was stained with diaminobenzidine (brown) and OX6 or ED2 with Fast Blue (blue). A, Double staining using anti-MIP-1 $\alpha$ and OX6 in normal rat $(\times 640)$. B, Double staining using anti-MIP-1 $\alpha$ and ED2 in normal rat $(\times 640)$. C, Double staining using anti-MIP-1 $\alpha$ and 0 X6 in myosin-immunized rats on Day $11.0 X 6^{+}$MIP- $1 \alpha^{+}$cells were found to have gathered together $(\times 640)$. D, 0X6-positive cells formed large clusters in myosin-immunized rats on Day $14(\times 100)$. E, In situ RT-PCR for MIP-1 $\alpha$ mRNA $(\times 320)$. Positive signal was detected by a direct immunoperoxidase method using diaminobenzidine (brown) on Day 14. F, Negative control omitting RT enzyme $(\times 320)$. D to F, The sections were counterstained with hematoxylin.

\section{Kinetics of OX6- or ED2-Positive Cells}

The number of OX6- or ED2-stained cells that were also predominantly immunoreactive for MIP- $1 \alpha$ by Day 14 was calculated from Day 0 to Day 14 (Fig. 4). On Day 0 the number of $\mathrm{OX6}^{+}$MIP- $1 \alpha^{+}$cells and ED2 ${ }^{+}$MIP $-1 \alpha^{+}$cells per $\mathrm{mm}^{2}$ was $57 \pm 6$ and $113 \pm$
7, respectively. On Day $8, \mathrm{OX6}^{+} \mathrm{MIP}-1 \alpha^{+}$cells slightly decreased in number in the myosin-immunized rats $\left(42 \pm 4\right.$ cells $\left./ \mathrm{mm}^{2}\right)$ and control rats $\left(42 \pm 8\right.$ cells $\left./ \mathrm{mm}^{2}\right)$. In the myosin-immunized rats, the number of $\mathrm{OX6}^{+}$ MIP $-1 \alpha^{+}$cells per $\mathrm{mm}^{2}$ returned to normal on Day 11 (54 \pm 10$)$ and significantly increased on Day 14 (89 \pm 14) $(p<0.001)$. In the control rats, however, the 
(A)

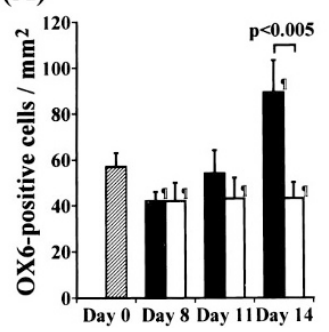

(B)

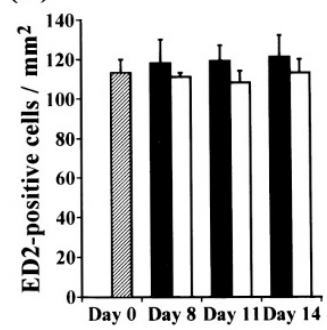

Figure 4.

Kinetics of OX6- or ED2-positive cells in EAM. A, The number of OX6-positive cells in EAM rats (solid bars) and control rats (open bars). B. The number of ED2-positive cells in EAM and control rats. I, $p<0.05$ compared with normal rats (hatched bars).

number of $\mathrm{OX6}^{+} \mathrm{MIP}-1 \alpha^{+}$cells did not increase at these stages. In contrast to the OX6-positive cells, the number of ED2 ${ }^{+}$MIP $-1 \alpha^{+}$cells stayed at normal levels from Day 8 to Day 14 in both the myosin-immunized rats and the control rats (Fig. 4).

\section{Administration of Anti-MIP-1 $\alpha$ Antibody}

The heart weight per body weight ratio $(\mathrm{mg} / \mathrm{g})$ in Group A (myosin-immunized rats), Group B (myosinimmunized rats treated with anti-MIP- $1 \alpha$ antibody on Days 11, 13, and 15), and Group C (myosinimmunized rats treated with anti-MIP- $1 \alpha$ antibody on Days 14, 16, and 18) was $7.9 \pm 0.9,6.7 \pm 0.3$, and 7.4 \pm 0.3 , respectively. The ratio was significantly smaller in Group B than in Group A $(p<0.05)$. Tissue specimens from rats in Groups $A$ and $C$ exhibited marked infiltration by inflammatory cells, including lymphocytes, macrophages, neutrophils, and giant cells with extensive necrosis of cardiac myocytes. In contrast, the infiltration of the myocardium by inflammatory cells and necrosis of myocytes was reduced in Group B (Fig. 5). As shown in Figure 6, the affected area ratio in Groups A, B, and C was $51 \pm 6 \%, 27 \pm$ $4 \%$, and $50 \pm 6 \%$, respectively. The affected area was significantly smaller in Group B than in Groups A or C $(p<0.0001)$. However, there was no significant difference between Group A and rats treated with rabbit $\operatorname{lgG}(1 \mathrm{mg} / \mathrm{kg})$ on Days 11,13 , and $15(47 \pm 5 \%)$.

\section{Discussion}

In this study, expression of MIP- $1 \alpha$ mRNA was enhanced in the hearts of EAM rats starting from Day 11 compared with control rats, and serial treatment with anti-MIP- $1 \alpha$ antibody on Days 11,13 , and 15 was effective in reducing myocardial lesion in EAM. This effect of anti-MIP- $1 \alpha$ was specific, because an equivalent dosage of normal rabbit IgG had no effect on the suppression of myocardial damage. The administration of anti-MIP-1 $\alpha$ after Day 14, however, did not prevent the development of EAM.

The onset of EAM occurs approximately 2 weeks after the injection of cardiac myosin (Kodama et al, 1991). At this time small numbers of CD $4^{+} T$ cells and macrophages also start to infiltrate the myocardium.
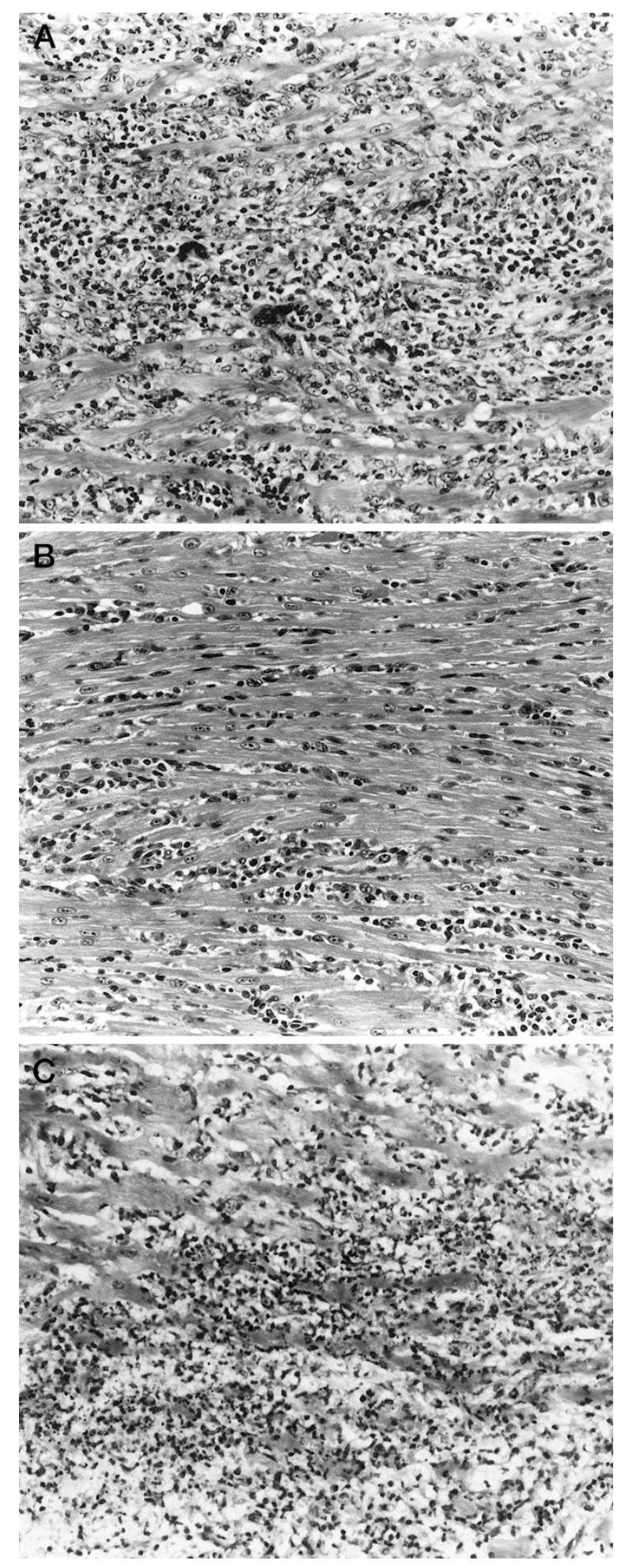

Figure 5.

Histopathologic findings. A (Group A) and C (Group C), Marked inflammatorycell infiltration, such as lymphocytes, macrophages, neutrophils, and giant cells and extensive necrosis of cardiac myocytes is noted ( $\times 200)$. B (Group B), Anti-MIP-1 $\alpha$ antibody reduced the infiltration into the myocardium by inflammatory cells and the necrosis of myocytes $(\times 200)$.

Because MIP- $1 \alpha$ drives type 0 helper T cells to differentiate to type 1 helper T cells (Karpus and Kennedy, 1997), several cytokines may be produced by type 1 helper T cells or macrophages on Day 14. In addition, 
(A)
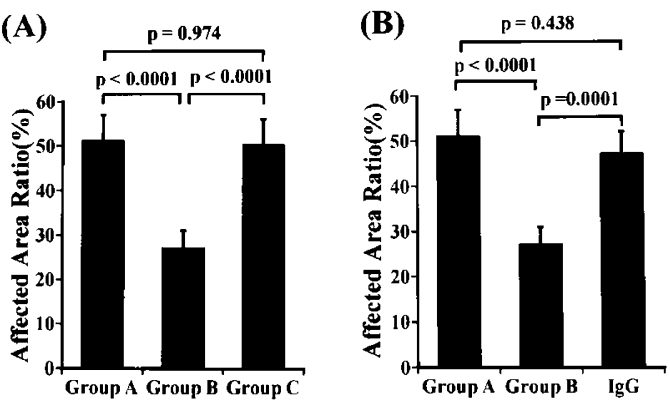

Figure 6.

Affected area ratio. A, The area ratio in Groups A $(n=10), \mathrm{B}(n=5)$, and C $(n=5)$ was $51 \pm 6 \%, 27 \pm 4 \%$, and $50 \pm 6 \%$, respectively. B, The group treated with normal rabbit IgG on Days 11,13 , and $15(47 \pm 5 \%)$ was not statistically different from Group A.

MIP- $1 \alpha$ can act as an autocrine and/or a paracrine regulator (Fahey et al, 1992; Graham et al, 1990), stimulating the secretion of tumor necrosis factor by macrophages (Fahey et al, 1992). In fact, in EAM, strong expression of type 1 helper $\mathrm{T}$ cell cytokine (interleukin-2 mRNA) was seen at Day 14 and proinflammatory cytokines (interleukin- $1 \beta$ and tumor necrosis factor- $\alpha$ ) were detected during the maximum inflammatory phase on Day 19 (Okura et al, 1997). MIP- $1 \alpha$, therefore, may play a role in the initial recruitment of inflammatory infiltrate in EAM, as seen in an autoimmune encephalomyelitis model (Karpus et al, 1995). After the initial cell recruitment on Day 14, pro-inflammatory and T cell-stimulatory cytokines, ie, interleukin- $1 \beta$, interferon- $\gamma$, tumor necrosis factor- $\alpha$, and interleukin-2, may take the place of MIP- $1 \alpha$ in the development of EAM.

MIP- $1 \alpha$ shares many of its pro-inflammatory and chemotactic functions with other members of the C-C chemokine family. Many of the pro-inflammatory chemokines are up-regulated in CVB-induced myocarditis (Gebhard et al, 1998; Kishimoto et al, 2000). Because anti-MIP-2 treatment prevented inflammatory response in CVB-induced myocarditis, MIP-2 was considered to be a major neutrophil and lymphocyte chemoattractant contributing to myocardial influx or infiltration in viral myocarditis (Kishimoto et al, 2000). Therefore, although MIP- $1 \alpha$ is blocked by neutralizing antibodies, other chemokines, as seen in CVB-induced myocarditis, may induce inflammatory responses.

Production of MIP- $1 \alpha$ in the central nervous system correlates with development of severe clinical disease in experimental autoimmune encephalomyelitis, which is a CD4+ T cell-mediated, inflammatory demyelinating disease of the central nervous system. Antibodies to MIP-1 $\alpha$ have also been shown to ameliorate encephalomyelitis in the mouse (Karpus et al, 1995). In the murine type II collagen-induced arthritis animal model of rheumatoid arthritis, treatment with antibody to MIP- $1 \alpha$ or MIP-2 decreased the severity of the disease (Kasama et al, 1995). Taken together these data indicate that MIP- $1 \alpha$ may play an important role in the development of several autoimmune diseases, including EAM, encephalomyelitis, and arthritis.
It is not clear what cell type produces MIP- $1 \alpha$ in autoimmune diseases. In this study, MIP- $1 \alpha$ mRNA was detected in normal rat heart, and immunoreactivity was revealed in OX6- and ED2-positive cells. During development of myocarditis, the expression of MIP- $1 \alpha$ mRNA was enhanced in EAM rats compared with control rats, and the extent of the increase grew from 4-fold (Day 11) to 8-fold at its peak (Day 17). By Day 14, before the onset of EAM, the major population of MIP- $1 \alpha$-positive cells was also OX6- or ED2positive. MIP- $1 \alpha$, therefore, may be produced primarily by OX6-positive or ED2-positive cells before the onset of EAM.

$\mathrm{OX6}^{+}$MIP $-1 \alpha^{+}$cells were seen approximately one half as frequently as ED2 ${ }^{+} \mathrm{MIP}-1 \alpha^{+}$cells in normal rats, as reported previously (Suzuki, 1995). Before the onset of EAM, the number of $0 \times 6^{+}$ MIP $-1 \alpha^{+}$cells transiently decreased on Day 8 and then gradually increased from Day 11 in myosinimmunized rats, but not in control rats. The increase in $\mathrm{OX6}^{+}$MIP- $1 \alpha^{+}$cells in myosin-immunized rats was 2-fold on Day 14 compared with control rats. However, the number of ED2 ${ }^{+}$MIP- $1 \alpha^{+}$cells remained at normal levels in both myosin-immunized and control rats. The change in the number of OX6-positive cells corresponded with the change in the levels of MIP- $1 \alpha$ mRNA in both groups. Using in situ RT-PCR with primers for MIP- $1 \alpha$ mRNA, MIP- $1 \alpha$ transcripts were detected in mononuclear cells, especially in clustering cells, on Day 14. Immunohistochemical study revealed that most of clustering cells were composed of OX6 ${ }^{+}$MIP- $1 \alpha^{+}$cells. OX6 mouse anti-rat la (MHC class II) antibody has been used to identify cardiac dendritic cells (DC) (Darden et al, 1987). Immunohistochemical and ultrastructural findings have suggested that OX6-positive cells present in the early phase of EAM were cardiac DC (Suzuki, 1995). In general, DC can activate immunologically naive $T$ cells in the initiation of cell-mediated immune reaction (Steinman, 1991). Langerhans cells, characterized by nonlymphoid DC in the skin, synthesize and secrete interleukin-1 $\beta$ and interleukin-6, cytokines known to be important accessory molecules in T cell activation (Schreiber et al, 1992). Langerhans cells are the major source of MIP- $1 \alpha$ mRNA in the skin (Heufler et al, 1992; Matsue et al, 1992). OX6-positive cardiac DC, therefore, rather than $\mathrm{ED}^{+}{ }^{+}$resident macrophages, are the main producers of MIP- $1 \alpha$ during the initiation of EAM, similarly to Langerhans cells in the skin. MIP $-1 \alpha$ produced by cardiac DC may regulate the initial recruitment of $\mathrm{CD} 4^{+} \mathrm{T}$ cells and macrophages in the myocardium. Cardiac DC may then activate these cells to initiate the cell-mediated immune reaction.

In conclusion, MIP-1 $\alpha$ mRNA is highly expressed in experimental rat myocarditis. Administration of antibody against MIP- $1 \alpha$ reduces myocardial inflammation when treated before onset of initial inflammation. MIP- $1 \alpha$ may regulate the recruitment of inflammatory cells in the early stages of EAM and play an important role in the development of EAM. 


\section{Materials and Methods}

\section{Animals}

Female 7-week-old Lewis rats were purchased from Charles River Japan Inc. (Kanagawa, Japan) and maintained at the Laboratory Animal Center, School of Medicine, Chiba University, Chiba, Japan.

\section{Induction of EAM}

The protocol for these experiments was approved by the Special Committee on Animal Welfare of the Inohana Campus of Chiba University. EAM was induced in rats as previously described (Ishiyama et al, 1997, 1998; Kodama et al, 1991). Rats were immunized twice, with a 7-day interval between injections, by foot pad injection of $10 \mathrm{mg} / \mathrm{mL}$ of porcine cardiac myosin (Sigma Chemical, St. Louis, Missouri) emulsified in Freund's complete adjuvant (Sigma Chemical) or in adjuvant alone for control rats. Rats were then injected with $0.1 \mathrm{~mL}$ of Bordetella pertussis (Nacalai Tesque, Kyoto, Japan) dissolved in $0.9 \mathrm{~mL}$ of saline solution via the caudal vein, 2 and 5 days after the first immunization.

\section{Reverse-Transcription Polymerase Chain Reaction}

Hearts were removed from five myosin-immunized rats and three control rats on Days 8, 11, 14, 17, and 21 after the first immunization and from five normal rats on Day 0 . A transverse section from each rat was embedded in Optimal Cutting Temperature Compound (OCT Compound; Miles Laboratories, Naperville, Illinois) and rapidly frozen in liquid nitrogen for immunohistochemical evaluation. The rest of the tissue was frozen in liquid nitrogen for RNA isolation. Total RNA was prepared from the myocardium using the RNeasy MIDI Kit (Qiagen, Hilden, Germany). cDNA was synthesized from $1 \mu \mathrm{g}$ of total RNA using random hexamer oligonucleotides $\left(\mathrm{pd}[\mathrm{N}]_{6}\right.$; Pharmacia P-L Biochemical, Milwaukee, Wisconsin) and M-MLV reverse transcriptase (Life Technologies, Gaithersburg, Maryland) using a standard protocol. Two microliters of the cDNA reaction mixture were used as a template for PCR. The following sense/ antisense primers were used for amplification of MIP-1 $\alpha$ cDNA (Natori et al, 1997; Shi et al, 1995): 5'-TCAGCACCATGAAGGTCTCCAC-3' and 5'-CTCAGGCATITAGTTCCAGCTC-3'. The efficiency of the cDNA synthesis from each sample was estimated by RT-PCR with GAPDH sense/antisense primers (Natori et al, 1997): 5'-TTCTACCCACGGCAAGTTCAA-3' and 5'-GGATGACCTTGCCCACAGC-3'. Amplification was performed for 33 cycles (MIP-1 $\alpha$ ) or 25 cycles (GAPDH) with a denaturing temperature of $94^{\circ} \mathrm{C}$ for 1 minute, an annealing temperature $63^{\circ} \mathrm{C}$ for 2 minutes, and an extension temperature $72^{\circ} \mathrm{C}$ for 3 minutes. The PCR procedure was performed at least three times for each sample. RT-PCR products were separated on a $3 \%$ agarose gel. Signals were evaluated by densitometry using the National Institutes of Health (NIH) Image 1.59 software program ( $\mathrm{NIH}$, Bethesda, Maryland) and the ratio of intensity of MIP- $1 \alpha$-specific signal to intensity of
GAPDH-specific signal (MIP- $1 \alpha$-signal/GAPDH-signal) was calculated. The optimal number of amplification cycles and the annealing temperature used for semiquantitative RT-PCR were chosen on the basis of previously published data to be within the linear range of the reaction (Natori et al, 1997).

\section{Immunohistochemical Study}

Cryostat sections were cut sequentially at $4 \mu \mathrm{m}$ and fixed in acetone for 10 minutes. To identify inflammatory cells, we used mouse monoclonal antibodies against OX6 (Serotec Ltd., Oxford, United Kingdom), which recognizes major histocompatibility complex (MHC) class II-expressing cells, including DC, some macrophages, and B lymphocytes; ED1 (PharMingen, San Diego, California), a marker for inflammatory macrophages; ED2 (BioSource International, Camarillo, California), a marker for resident macrophages; OX19 (Serotec Ltd.), a marker for pan-T cells; W3/25 (Serotec Ltd.), a marker for CD4 T cells; OX8 (Serotec Ltd.), a marker for CD8 T cells; and OX33 (Serotec Ltd), a marker for $\mathrm{B}$ cells. Double staining using rabbit anti-rat MIP-1 $\alpha$ (BioSource International) and ED1, ED2, OX6, OX19, W3/ 25 , OX8, or OX33 on a single section was done using a modified Nakane method (Nakane, 1968). MIP-1 $\alpha$ was localized by the streptavidin-biotin complex method performed according to a standard protocol for a Histofine SAB-PO Kit from Nichirei (Tokyo, Japan). Antibodies were removed from the sections by glycine-hydrochloric acid buffer, $\mathrm{pH}$ 2.2, leaving the colored reaction products of diaminobenzidine. The second antigen was localized similarly, using the Fast Blue Substrate Kit (Nichirei), which develops reaction products of a different color from diaminobenzidine. The number of immunohistochemical-stained cells was calculated using a CAS 200 (Becton Dickenson, San Jose, California). The resultant data were expressed as the mean number \pm SD per $\mathrm{mm}^{2}$.

\section{In Situ Reverse Transcription-Polymerase Chain Reaction}

The heart sections were fixed in $4 \%$ paraformaldehyde in $0.1 \mathrm{M}$ phosphate buffer, $\mathrm{pH} 7.4$, overnight at $4^{\circ} \mathrm{C}$ for in situ RT-PCR (Martinez et al, 1995), embedded in paraffin, and cut into $4-\mu \mathrm{m}$-thick sections. After dewaxing, the samples were boiled in $10 \mathrm{~mm}$ citrate buffer, pH 6.0. First strand cDNA was synthesized by adding approximately $10 \times$ RNA PCR buffer (Takara Shuzo, Shiga, Japan), 5 mм MgCL 2,1 mm dNTPs, 60 U RNasin (Promega, Madison, Wisconsin), 25 U AMV RTase XL (Takara Shuzo), and $2.5 \mu \mathrm{M}$ antisense primer, and incubating at $42^{\circ} \mathrm{C}$ for 1 hour. The samples were then exposed to $1 \mathrm{U} / \mu \mathrm{L}$ DNase (Roche Molecular Biochemicals, Mannheim, Germany) in $1 \times$ PCR buffer overnight at $37^{\circ} \mathrm{C}$. For PCR, amplifications were carried out in a reaction mixture of $10 \times$ Ex Taq Buffer (Takara Shuzo), $2.5 \mathrm{~mm} \mathrm{MgCl}_{2}, 0.2 \mathrm{~mm}$ dNTPs, $20 \mu \mathrm{M}$ digoxigenin-11-dUTP (Boehringer Mannheim, Mannheim, Germany), $0.8 \mu \mathrm{m}$ each primer, 8.5 U TaKaRa Ex Taq (Takara Shuzo). The samples were heated to $94^{\circ} \mathrm{C}$ for 3 minutes, cycled at $94^{\circ} \mathrm{C}$ for 1 minute, $60^{\circ} \mathrm{C}$ for 1 minute, and $68^{\circ} \mathrm{C}$ for 1.5 minutes, for 30 cycles, and then cooled. The samples 
were incubated with $2 \%$ blocking reagent (Boehringer Mannheim) in blocking buffer (100 mm Tris- $\mathrm{HCl}, \mathrm{pH}$ 7; $150 \mathrm{~mm} \mathrm{NaCl}$; $0.1 \%$ Tween 20) at room temperature for 30 minutes and then reacted with antidigoxigenin antibody conjugated with horse-radish peroxidase (Boehringer Mannheim) at room temperature for 30 minutes. The labeling peroxidase was visualized with diaminobenzidine and hydrogen peroxide. Omission of AMV RTase XL was used as negative control.

\section{Neutralization of MIP-1a}

We investigated the effects of rabbit anti-rat MIP-1 $\alpha$ neutralizing antibody (BioSource International) in EAM. Rats were divided into three groups: Group A consisted of myosin-immunized rats $(n=10)$, Group B consisted of myosin-immunized rats treated with antiMIP-1 $\alpha(1 \mathrm{mg} / \mathrm{kg})$ on Days 11, 13, and $15(n=5)$, and Group $\mathrm{C}$ consisted of myosin immunized rats treated with anti-MIP-1 $\alpha(1 \mathrm{mg} / \mathrm{kg})$ on Days 14,16 , and 18 (n $=5$ ). Rats were euthanized on Day 21 to determine the percentage of the area affected by inflammatory lesions on the basis of a previous report (Ishiyama et al, 1997, 1998). Three transverse sections of the heart from each rat were prepared, fixed in $10 \%$ buffered formalin, embedded in paraffin, cut into 3- $\mu \mathrm{m}$-thick sections and stained with hematoxylin and eosin. Areas of the entire heart and regions affected by myocarditis with infiltration by inflammatory cells and myocardial necrosis were determined with the $\mathrm{NIH}$ Image 1.59 software program and the area ratio (affected area/entire area, as a percentage) was calculated.

\section{Statistical Analysis}

Results are expressed as mean $\pm \mathrm{SD}$. Student's $t$ test was used for the comparison between the two groups. Statistical significance of differences among the three groups was assessed by one-way analysis of variance (ANOVA) and Scheffe's multiple comparison method test. Findings of $p<0.05$ were considered statistically significant.

\section{References}

Badorff C, Lee GH, Lamphear BJ, Martone ME, Campbell KP, Rhoads RE, and Knowlton KU (1999). Enteroviral protease 2A cleaves dystrophin: Evidence of cytoskeletal disruption in an acquired cardiomyopathy. Nat Med 5:320-326.

Cook DN (1996). The role of MIP-1 $\alpha$ in inflammation and hematopoiesis. J Leukoc Biol 59:61-66.

Cook DN, Beck MA, Coffman TM, Kirby SL, Sheridan JF, Pragnell IB, and Smithies O (1995). Requirement of MIP-1 $\alpha$ for an inflammatory response to viral infection. Science 269:1583-1585.

Costa JJ, Matossian K, Resnick MB, Beil WJ, Wong DTW, Gordon JR, Dvorak AM, Weller PF, and Galli SJ (1993). Human eosinophils can express the cytokines tumor necrosis factor- $\alpha$ and macrophage inflammatory protein $-1 \alpha$. J Clin Invest 91:2673-2684.
Davatelis G, Tekamp-Olson P, Wolpe SD, Hermsen K, Luedke C, Gallegos C, Coit D, Merryweather J, and Cerami A (1988). Cloning and characterization of a cDNA for murine macrophage inflammatory protein (MIP), a novel monokine with inflammatory and chemokinetic properties. J Exp Med 167:1939-1944.

Darden AG, Clarke RD, and Guttmann RD (1987). Rat cardiac dendritic cells: Frequency in inbred and congenic rats. Transplant Proc 19:208.

Fahey TJ III, Tracey KJ, Tekamp-Olson P, Cousens LS, Jones WG, Shires GT, Cerami A, and Sherry B (1992). Macrophage inflammatory protein 1 modulates macrophage function. J Immunol 148:2764-2769.

Gauntt CJ, Arizpe HM, Higdon AL, Rozek MM, Crawley R, and Cunningham MW (1991). Anti-coxsackievirus B3 neutralizing antibodies with pathological potential. Eur Heart $\mathrm{J}$ 12(Suppl D):124-129.

Gauntt CJ, Higdon AL, Arizpe HM, Tamayo MR, Crawley R, Henkel RD, Pereira MEA, Tracy SM, and Cunningham MW (1993). Epitopes shared between coxsackievirus B3 (CVB3) and normal heart tissue contribute to CVB3-induced murine myocarditis. Clin Immunol Immunopathol 68:129-134.

Gebhard JR, Perry CM, Harkins S, Lane T, Mena I, Asensio VC, Campbell IL, and Whitton JL (1998). Coxsackievirus B3-induced myocarditis: Perforin exacerbates disease, but plays no detectable role in virus clearance. Am J Pathol 153:417-428.

Graham GJ, Wright EG, Hewick R, Wolpe SD, Wilkie NM, Donaldson D, Lorimore S, and Pragnell IB (1990). Identification and characterization of an inhibitor of haemopoietic stem cell proliferation. Nature 344:442-444.

Hanawa $\mathrm{H}$, Tsuchida M, Matsumoto $\mathrm{Y}$, Watanabe $\mathrm{H}$, Abo T, Sekikawa $H$, Kodama M, Zhang S, Izumi T, and Shibata A (1993). Characterization of T cells infiltrating the heart in rats with experimental autoimmune myocarditis: Their similarity to extrathymic $T$ cells in mice and the site of proliferation. $\mathrm{J}$ Immunol 150:5682-5695.

Heufler C, Topar G, Koch F, Trockenbacher B, Kämpgen E, Romani N, and Schuler G (1992). Cytokine gene expression in murine epidermal cell suspensions: Interleukin $1 \beta$ and macrophage inflammatory protein $1 \alpha$ are selectively expressed in Langerhans cells but are differentially regulated in culture. J Exp Med 176:1221-1226.

Horwitz MS, Cava AL, Fine C, Rodriguez E, llic A, and Sarvetnick N (2000). Pancreatic expression of interferon- $\gamma$ protects mice from lethal coxsackievirus B3 infection and subsequent myocarditis. Nat Med 6:693-697.

Ishiyama S, Hiroe M, Nishikawa T, Abe S, Shimojo T, Iro H, Ozasa S, Yamakawa K, Matsuzaki M, Mohammed MU, Nakazawa H, Kasajima T, and Marumo F (1997). Nitric oxide contributes to the progression of myocardial damage in experimental autoimmune myocarditis in rats. Circulation 95:489-496.

Ishiyama S, Hiroe M, Nishikawa T, Shimojo T, Abe S, Fujisaki $\mathrm{H}$, Ito $\mathrm{H}$, Yamakawa $\mathrm{K}$, Kobayashi $\mathrm{N}$, Kasajima $\mathrm{T}$, and Marumo $F$ (1998). The Fas/Fas ligand system is involved in the pathogenesis of autoimmune myocarditis in rats. $\mathrm{J} \mathrm{Im}$ munol 161:4695-4701.

Karpus WJ and Kennedy KJ (1997). MIP-1 $\alpha$ and MCP-1 differentially regulate acute and relapsing autoimmune encephalomyelitis as well as $\mathrm{TH} 1 / \mathrm{TH} 2$ lymphocyte differentiation. J Leukoc Biol 62:681-687. 
Karpus WJ, Lukacs NW, McRae BL, Strieter RM, Kunkel SL, and Miller SD (1995). An important role for the chemokine macropharge inflammatory protein- $1 \alpha$ in the pathogenesis of the $T$ cell-mediated autoimmune disease, experimental autoimmune encephalomyelitis. J Immunol 155:5003-5010.

Kasama T, Strieter RM, Lukacs NW, Lincoln PM, Burdick MD, and Kunkel SL (1995). Interleukin-10 expression and chemokine regulation during the evolution of murine type II collagen-induced arthritis. J Clin Invest 95:2868-2876.

Kasama T, Strieter RM, Standiford TJ, Burdick MD, and Kunkel SL (1993). Expression and regulation of human neutrophil-derived macrophage inflammatory protein $1 \alpha$. J Exp Med 178:63-72.

Kishimoto C, Kawamata H, Sakai S, Shinohara H, and Ochiai H (2000). Role of MIP-2 in coxsackievirus B3 myocarditis. $\mathrm{J}$ Mol Cell Cardiol 32:631-638.

Kodama M, Hanawa $H$, Saeki $M$, Hosono $H$, Inomata $T$, Suzuki K, and Shibata A (1994). Rat dilated cardiomyopathy after autoimmune giant cell myocarditis. Circ Res 75:278284.

Kodama M, Matsumoto Y, Fujiwara M, Zhang S, Hanawa $H$, Itoh E, Tsuda T, Izumi T, and Shibata A (1991). Characteristics of giants cells and factors related to the formation of giant cells in myocarditis. Circ Res 69:1042-1050.

Kodama M, Zhang S, Hanawa H, and Shibata A (1992). Imnohistochemical characterization of infiltrating mononuclear cells in the rat heart with experimental autoimmune giant cell myocarditis. Clin Exp Immunol 90:330-335.

Lukacs NW, Chensue SW, Smith RE, Strieter RM, Warmington K, Wilke C, and Kunkel SL (1994). Production of monocyte chemoattractant protein-1 and macrophage inflammatory protein- $1 \alpha$ by inflammatory granuloma fibroblasts. Am J Pathol 144:711-718.

Martinez A, Miller MJ, Quinn K, Unsworth EJ, Ebima M, and Cuttitta F (1995). Non-radioactive localization of nucleic acids by direct in situ PCR and in situ RT-PCR in paraffinembedded sections. J Histochem Cytochem 43:739-747.

Matsue H, Cruz PD Jr, Bergstresser PR, and Takashima A (1992). Langerhans cells are the major source of mRNA for $\mathrm{IL}-1 \beta$ and MIP- $1 \alpha$ among unstimulated mouse epidermal cells. J Invest Dermatol 99:537-541.

Nakane PK (1968). Simultaneous localization of multiple tissue antigens using the peroxidase-labeled antibody method: A study of pituitary glands of the rat. J Histochem Cytochem 16:557-560.

Natori Y, Sekiguchi M, Ou Z, and Natori Y (1997). Gene expression of $\mathrm{CC}$ chemokines in experimental crescentic glomerulonephritis (CGN). Clin Exp Immunol 109:143-148.
Okura Y, Yamamoto T, Goto S, Inomata T, Hirono S, Hanawa $\mathrm{H}$, Feng L, Wilson CB, Kihara I, Izumi T, Shibata A, Aizawa Y, Seki S, and Abo T (1997). Characterization of cytokine and iNOS mRNA expression in situ during the course of experimental autoimmune myocarditis in rats. $\mathrm{J} \mathrm{Mol} \mathrm{Cell} \mathrm{Cardiol}$ 29:491-502.

Oppenheim JJ, Zachariae COC, Mukaida N, and Matsushima K (1991). Properties of the novel proinflammatory supergene "intercrine" cytokine family. Annu Rev Immunol 9:617-648.

Rose NR (2000). Virul damage or "molecular mimicry"placing the blame in myocarditis. Nat Med 6:631-632.

Schall TJ (1991). Biology of the RANTES/SIS cytokine family. Cytokine 3:165-183.

Shi MM, Godleski JJ, and Paulauskis JD (1995). Molecular cloning and posttranscriptional regulation of macrophage inflammatory protein- $1 \alpha$ in alveolar macrophages. Biochem Biophys Res Commun 211:289-295.

Schreiber S, Kilgus O, Payer E, Kutil R, Elbe A, Mueller C, and Stingl $G$ (1992). Cytokine pattern of Langerhans cells isolated from murine epidermal cell cultures. J Immumol 149:35253534 .

Smith SC and Allen PM (1991). Myosin-induced acute myocarditis is a T cell-mediated disease. $\mathrm{J} \mathrm{Immunol} \mathrm{147:2141-}$ 2147.

Steinman RM (1991). The dendritic cell system and its role in immunogenicity. Annu Rev Immunol 9:271-296.

Strieter RM, Standiford TJ, Huffnagle GB, Colletti LM, Lukacs NW, and Kunkel SL (1996). The good, the bad, and the ugly: The role of chemokines in models of human disease. J Immunol 156:3583-3586.

Suzuki K (1995). A histological study on experimental autoimmune myocarditis with special reference to initiation of the disease and cardiac dendritic cells, Virchows Arch 426:493500.

Taub DD, Conlon K, Lloyd AR, Oppenheim JJ, and Kelvin DJ (1993). Preferential migration of activated $\mathrm{CD}^{+}$and $\mathrm{CD}^{+} \mathrm{T}$ cells in response to MIP-1 $\alpha$ and MIP-1 $\beta$. Science 260:355358.

Wolpe SD, Davatelis G, Sherry B, Beutler B, Hesse DG, Nguyen HT, Moldawer LL, Nathan CF, Lowry SF, and Cerami A (1988). Macrophages secrete a novel heparin-binding protein with inflammatory and neutrophil chemokinetic properties. J Exp Med 167:570-581.

Woodruff JF (1980). Viral myocarditis. A review. Am J Pathol 101:425-484. 